\title{
REFLECTIONS ON THE VOCATION OF THE A RELIGIOUS EDUCATOR
}

John Elias

My first reaction upon hearing the theme for this year's conference was puzzlement. I never thought of myself as having a vocation to be a religious educator. Religious education is just one of the things I do, along with many other things. Perhaps this reaction reflects my Roman Catholic background where the word vocation most often bespeaks a calling to ordination as a priest or professions as a member of a religious order. I once had this kind of a vocation and perhaps have been hesitate to take the term to myself again.

After deciding that I should give a talk at an APRRE conference held in the city I call home, I have given much thought to my vocation as a religious educator. In what sense do I have a vocation as a religious education? My first task was to get at meaning of vocation that I could apply to what I have done for the past forty years. I then present a number of scenarios that reveal my vocation as a religious educator. Finally, I offer some reflections on these scenarios as they reflect my vocation. Perhaps these reflections may help you contemplate the distinctive quality of your vocation.

\section{$\underline{\text { Vocation }}$}

The word vocation has a long usage in both religious and secular circles. From the Latin vocare, to call, the word has a biblical usage and a usage in ordinary language. The call in the Hebrew and Christian Scriptures was a summons from God to an individual inviting him or her to take up an important religious task. Abraham, Moses, Isaiah, Jeremiah, Judith, and Esther all received calls from God to become leaders and spokespersons for divine purposes. Many viewed themselves as unworthy and unprepared for their summons. They often struggled valiantly with their calling. But they usually carried out what they were asked to do.

Calling is a prominent event in the Christian Scriptures. Each of the four Gospels records the call by Jesus of individuals to be apostles and disciples. The call was to leave all, including family members, and follow Jesus. The call often entailed significant sacrifice and commitment. On one occasion Jesus called a young man to be a disciple but the young man did not follow the call, because he had many possessions.

Calling takes on a deep theological meaning in the writings of the Apostle Paul. Calling is election by God. Paul writes eloquently of his own calling, making a case that he is an apostle equal to the other apostles called by Jesus. He also writes profoundly of calling or election as a summons to salvation and an invitation to participate in the 
redemptive activity of Jesus. Thus calling for Paul is an election by God for a deeply religious mission.

According to one writer vocation in the biblical tradition has these four characteristics, A person is called for a specific purpose to which he or she must make a commitment. The called person has a special gift for accomplishing this purpose. A vocation presumes a person who calls, Yahweh, God, Jesus. To accept a vocation means to live a life of sacrifice, to live with faith in darkness. (VanOosting 2002, 11).

In the medieval church those called were persons chosen for the life of clerics or religious. This understanding of vocation has continued in the Catholic tradition where vocations have almost always meant a calling to a priestly or vowed religious life. Though many attempts have been made to include other meanings of vocation in Catholic life, such as vocation to the single state, marriage or work, for many Catholics praying for vocations still means praying for more priests, sisters, and brothers. An internet search engine on vocations indicates how pervasive this meaning still is in Catholic circles.

This medieval and Catholic view of vocation resonates with the theology of vocation expressed by two prominent Jesuit theologians:

[Vocation is] the recognition by an individual that a particular career (mode of life) corresponds to God's permissive or jussive will for him and is the life work in which he can gain his eternal salvation. To this extent any career, even one that is disliked, can be a vocation, since one may have a duty to do what one finds difficult. A vocation means in particular, but not exclusively, a call to the priesthood or the religious life. This is presumed where a person has the intellectual and moral qualities appropriate to such a state and has chosen it for the right (disinterested and religious) motives, and the Church is prepared to accept the services he would offer in her and for her in this state. (Rahner and Vorgrimler 1995, 483-4)

This theology of vocation adds a couple of interesting twists. God can either permit or order a person to follow a call. One's vocation is connected to eternal salvation. Though a person may not like his vocation, he or she may have to follow it out of a sense of duty. A vocation within the Church needs to be validated by the Church on the basis of person's intellectual qualities and their worthy motives.

The Protestant reformers Martin Luther and John Calvin considerably broadened the meaning of vocations to include all states of life as well as all work and occupations in society. They also voiced harsh criticism of the monastic vocation and the celibacy that it entailed, feeling that the great emphasis on these vocation $\mathrm{s}$ diminished the vocation of all Christians. For them every Christian has a calling to be a priest, to be religious. Christians are called to family life, occupations and work in the world. Every state of life is holy; every form of work is holy. All are called. 
The reformers' view of vocation appeared in our country in the Puritan use of the term. Vocation was one of the two signs that a person was a member of the covenant community. First, persons had to have an inner conversion experience of the transforming power of divine grace. Secondly, converted persons had to make a public commitment to a calling, or vocation, that took the form of disciplined and productive work. In this way Puritans were like the early monastic communities that believed that to work is to pray: While monks retreated from the world to live out their vocation, Puritans were called to live a pure, disciplined, and productive life working in human society. The worldly asceticism of ordinary Christians was of greater value that the otherworldly asceticism of monks. They were called to conquer the temptations of the world in their vocations of work. As John Winthrop put it, "For such trials as fall within the compass of our callings, it is better to arm and withstand them than to avoid and shun them."

Puritan vocation was a way of ascetic self-denial and spiritual discipline in the midst of the world. It was also a commitment to serve the community. Thus true Christian and Puritan faith found its expression in a calling that was of service to others. According to Cotton Mather, God approved of those who "live by faith in vocations, in that faith in serving God, serves men, and in serving men, serves God." The holy commonwealth was formed through the virtues of the rich -- temperance, mercy, and charity, and the virtues of the poor - faith, patience, and obedience. With the cultivation of all these virtues there developed a harmony of mutual dependency in which "everyman may have need of each other." (Chidester 2000, 393-4)

The reformers extension of vocation to all states and works in the world may have become the basis for a non-religious or secular meaning of vocation as including all secular states and works. However, the reformers interpretation of vocations as callings for all may have inadvertently separated the notion of vocation from its religious moorings. The same may be true of the word profession, which in its origins had a religious meaning, as in religious profession of priests, brothers, and nuns. There are so many professions. Perhaps the notion of service to others is the distinguishing characteristic of profession and vocation.

A secular meaning of vocation is found in the writings of Max Weber, who wrote on the vocation of the scientist and the vocation of politics. For Weber a sense of vocation existed when individuals were competent in what they did, made a firm commitment to carry out their work, and performed this work with passion , "for nothing is worthwhile for human being which he or she cannot do with passionate devotion (In Collins 1991, 40)." Michael Collins, a contemporary philosopher of adult education, attempts to retrieve a meaningful sense of vocation and mission utilizing Weberian categories. Vocation for him counters such notions as career advancement, professionalization, and upward social mobility. For Collins,

vocation refers to a calling and entails form commitment to the performance of worthwhile activities that are not merely calculated to advance personal career aspirations or fulfill minimum job expectations. It incorporates a strong ethical 
dimension, emphasizing an unavoidable necessity to make judgments about what should or should not be done and a readiness to take on significant issues.

(Collins 1991, 42)

The secular meaning of vocation has a prominent place in John Dewey's

philosophy of vocation. Dewey was a leader in the early $20^{\text {th }}$ century movement to bring vocational education into the schools. While for many of his contemporaries vocational education meant education in the manual trades, Dewey attempted to give a nobler interpretation of vocational education by probing the concept of vocation. For him persons have many vocations: wife, worker, parent, friend, citizen, etc. However, for Dewey among these many vocations that a person has there is one that makes the person distinctive and gives direction to the many activities of that person's life. Furthermore, for Dewey vocation includes the concept that in one's distinctive vocation one contributes to social service and social welfare. Thus for him vocation has a full intellectual and social meaning. Dewey argued, in the end unsuccessfully, for a concept of vocation and vocational education that would prepare persons not only their work in life but also for other functions and vocations required of them in a democratic society, including citizenship

Dewey described the vocation of educator and teacher as a distinctive and noble calling. He retained an element of the reformers' religious meaning of vocation in his My Pedagogical Creed where he expresses the belief that "every teacher should realize the dignity of his calling; that he is a social servant set apart for the maintenance of proper social order and the securing of the right social growth." Finally, he believed that "in this way the teacher always is the prophet of the true God and the usherer in of the true kingdom of God" (Dewey 1959, 32). This creed, written while Dewey was still a member of the Congregational Church, presented lofty beliefs on the vocation of the educator and the potential of education to reform society.

In summary, vocation bespeaks the distinctive life and work of an individual in so far as it contributes to the service of others in community and society. Vocation thus has both an individual and a social meaning. Vocation can be viewed in religious or secular terms. It is characterized by commitment, sacrifice service, and passionate devotion. On an individual level perhaps William James gives the telling sign: when engaged in an activity of one's true vocation one hears an inner voice which says: this is the real me.

\section{My Vocation as a Religious Educator: Some Scenarios}

The committee that composed the guidelines for this conference seemed to encourage personal voices and not just academic voices to be expressed in papers at this conference. I will attempt at times a personal voice, even though decades in academia have served to mute a personal voice, especially a personal voice in academic writing. There was little place for a personal voice in my principal areas of study: scholastic philosophy, manual theology, and analytic philosophy. However, in the last analysis all teaching is personal and autobiographical. Dr. Sal Messina, a former colleague, expressed this view; Whatever I teach I teach Sal Messina. 
Let me present you with a number of scenarios that portray aspects of my vocation as a religious educator. In a high school religion class in the early 1960's we studied the book of Job. In the class was a young boy, whom the entire class knew had a terminal illness. Job's metaphysical wrestling with the problem of why the good person suffer became an existential one for the class. Later, when I visited Dennis on his death bed, we talked at length about the book of Job. He said that the book was a great consolation for him and he thanked me and the class for the inspiring course. Years later I met his parents and they confirmed the spiritual guidance Dennis received from that course in the Hebrew Scriptures, especially from the book of Job.

While teaching biblical literature in the sixties I came under criticism from parents of my students for the modern interpretations I offered on different parts of the Bible. I decided to give the same course in the evenings to the parents of my students. About a hundred persons attended the course. It was an exhilarating experience to explain the Scriptures to an adult audience and to have the entire group relate the readings, lectures, and discussions to their lives. At the end of the course I received a standing ovation and was taken out for a grand dinner. Immediately I became an adult educator. No high school class ever gave me applause, let alone a free dinner.

While in graduate school at Temple University in the early 1970's I taught college theology courses at LaSalle College. One of my professors and my mentor, an avowed atheist and the most brilliant man I ever met, one day remarked to me. "Why do you teach religion and theology? They do not have any answers." I replied: "Jim, I know they don't have the answers but they seem to ask all the right questions."

One Lent in the early 1980's I conducted the Ashes to Easter Lenten program in the home Dr. Al Graziano, a physician who was bedridden with a terminal illness. The Lenten observance came movingly alive for our small group as we discussed penance, sacrifice, suffering, redemption, and fasting in an atmosphere of both depth and humor. A small faith community emerged, spawning friendships that lasted for years and that supported his widow upon Dr. Al's death.

While watching television with my wife one evening, I was startled to see young woman Linda Perez on the screen. She was speaking energetically at a public rally in the South Bronx to protest the construction of a giant incinerator, which her activist group viewed as a serious health hazard. Linda had recently completed a course I helped to design and conduct for the South Bronx Churches, whose intended purpose was to train religious leaders to become advocates for public and social betterment. At the beginning of the course she was diffident about public expressions of faith and even fearful of speaking in public.

Catherine comes to see me in my office. She brought a gift for me, her recently published book, Breaking the Silence: A Study of Teachers with Aids. The book began as a dissertation under my direction. We spent many hours together discussing ethics, forms of ethical discourse, the AIDS literature, the school as an ethical institution, and 
interviewing techniques. I surprised myself by experiencing more joy and satisfaction with her achievement than I did in any work that I had produced.

I spoke with David, a former doctoral student, about my difficulty in finishing the book to which I had already devoted many years. I cited Thomas Aquinas who was tempted to abandon his intellectual work, viewing it as so much straw. David, now a close friend, wrote me a poem on faith to encourage me to complete the task. He had earlier written another poem in his doctoral dissertation about the effect of my teaching and direction on him.

In my memory there are many other possible scenarios from four decades of educating in religion. However, these serve as the basis for reflections on the various aspects of my vocation as a religious educator. These are successes and highpoints. In these events and in many others I believe that I came close to achieving the sense of vocation of the religious education that my better self has aspired to. I know that there were also failures: students not reached; students turned off and disappointed, perhaps some even led astray.

\section{My Vocation as a Religious Educator: Some Reflections}

As a teacher of high school students I saw myself primarily as an instructor and spiritual guide. I embraced, without knowing it then, the ancient view of philosophy and religion as a way of life rather than a system of thought. The models for teaching were Jesus, Socrates, Plato, and Aristotle. In many ways I was more the spiritual father of the monastic culture than the medieval scholastic teacher. Time spent in the classroom was exciting but time outside the classroom was precious. Teaching teenagers in the sixties was easy and it was hard. It was easy to engage students in discussions about a church and a culture that were in the process of great change. Vatican II, the sexual revolution, the civil rights movement, the Vietnam War, the beginnings of the woman's movement and the ecology movement intruded most often into classroom discussions. Eventually, it became hard and difficult to both instruct and guide spiritually. I was going through many changes in my own life. Long-held certainties were dissolving.

Religious education in Catholic circles went through many changes in the decade of the sixties: traditional and doctrinal instruction, kerygmatic or proclamation teaching, , personal -existential probing, and political-social education. In a single decade we Catholic religious educators recapitulated what Protestant educators experienced in four or five decades. What remains in my mind most of the period was the care I took to plan instructional lessons in Scripture, liturgy, and morality and the time spent dealing one on one with the spiritual crises and doubts of youth. Teaching youth at that time was not teaching them about religion or teaching religion; it was trying to teach them to be religious and spiritual persons, to introduce them into a way a life that had its own beliefs and practices. It was not enough that they could answer questions about religion but of getting them to ask deep questions about religion and themselves. Being young myself, teaching young men and women, infused a passion into my teaching that I have rarely 
achieved in subsequent years. Perhaps it is the element of passion that separates a vocation from a job, a career, or even a profession.

One course with adults eventually shifted my vocation into an adult educator, even though I never formally studied adult education. Gabriel Moran and James Schaefer were our teacher in those days, calling for an adult education for an adult church. What made adult education especially satisfying was the rich experiences that adults brought to the classroom and the dramatic changes taking place in society and the Catholic church.. Adult Catholics brought up on the Baltimore catechism and an apologetic or defensive approach to Catholicism deep down knew that there was something more to the faith than what they had been previously taught..

In the 1960's armed with the new theology incorporated in Vatican II and the writings of prominent European theologians, my colleagues and I established adult education centers in each high school in a Pennsylvania diocese. We lectured extensively and enthusiastically. We provided adult education for all teachers in the Catholic schools and trained hundreds of catechists in the new catechetics, championed by Gerard Sloyan, Johannes Hofinger, Gabriel Moran, and the graduates of Lumen Vitae in Brussels. Later, I myself went on to graduate school where I encountered Paulo Freire, the adult educator par excellence of our era, and immersed myself in his thought and did dissertation on him.

There was a shift in my vocation as a religious educator when I moved to college and university teaching. The raising of questions, careful research, searching dialogue, and critical inquiry became primary modes of education. The shift might be described as moving from the Augustinian and monastic view of theology and education as faith seeking understanding to the scholastic and academic vocation of understanding seeking faith. My vocation as religious educator became what is now termed critical pedagogue. In working with undergraduate and graduate students a secure faith was not presumed. One could count on questioning, doubts, and at times intellectual combat. This was especially prevalent in undergraduate theology classes. The nurturing aspect of my vocation diminished as the critical approach prevailed. While theologians like Avery Dulles continued to call for a doctrinal and pastoral approach, I embraced the, to me, the more realistic stance of a Monica Hellwig, who described teaching of theology at Georgetown.

There seems to be an underlying assumption that a course on the subject matter of the student's own faith tradition ipso facto presumes the student's faith and adherence to his tradition. As one who regularly offers a course entitled Introduction to Catholic Theology to an undergraduate class which frequently contains Protestants, Jews, Muslims, Hindus, and others, I find the link between Catholic subject matter and the assumption of Catholic faith in the student out of touch with the present reality in our classrooms. (Hellwig 1997, 72)

Working in the seventies and eighties as a volunteer parish adult educator I explicitly added another dimension to my vocation as an adult educator: a builder of 
communities of dialogue. In parish adult education we used programs that consisted of small groups of participants sharing insights on faith in homes and parish rooms. In a Lenten program like Ashes to Easter, we met one day each week to reflect on the themes contained in the liturgies of that Sunday. Like the disciples around Jesus, like the disciples around Socrates and Plato, we approached our faith and philosophy not as a system of thought but as a way of life. My role was not that of instructor or guide but that of organizing and providing opportunities for sharing insights about the life of faith. At times instructional expertise was needed, to be imparted as briefly as possible. This same mode of education we used in the parish catechumenate for introducing new members into the parish. My distinctive vocation here was to encourage all to speak about their faith understandings and lives. We learned not merely from the words of Dr. Al but also from his life, as well as from the words and life of others. We learned because we were involved in one another's lives. We learned the truth of what the Stoic philosopher Seneca wrote many years ago:

The living word and life in common will benefit you more than written discourse. It is to current reality that you must go, first because people believe their eyes more than their ears, and then because the paths of precepts is long, but that of examples is short and infallible. Cleanthes [the Stoic] would not have imitated his master Zeno if he had been merely his auditor; but he was involved in his life, he penetrated his secret thoughts, and he was able to observe first hand whether Zeno lived in conformity with his own rule of life. Plato, Aristotle, and that whole crowd of sages which ended up in going in opposite directions--all derived more profit from Socrates' morals than from his words. It was not Epicurus' school which made great men of Metrodorus, Hermarchaus, and Polyaenus, but his companionship (Hadot 2002, 56-7

For a number of years I taught university courses on peace and justice. One of the frustrations of these courses was that for the most part the courses were about talk and not action. In working for South Bronx Churches I had the opportunity to bring theory and practice together. I became what both John Dewey and Paulo Freire called all educators to be, a social educator. Drawing on the principles of liberation theology and Freire's theory of conscientization and working with leaders of the Saul Alinsky founded Industrial Areas Foundation I us developed an ecumenical course to train religious leaders to become spiritually motivated agents for social change and betterment. I first gave a course to priests, ministers, imams, and lay leaders on the basics of the program. Then we offered the program to selected lay leaders.

For ten weeks groups of adult leaders, Protestant, Catholic, and Muslim met in a Church in the South Bronx. We began with prayer and reflections from the Jewish Scriptures, Christian Scriptures, and Koran. We shared experiences of problems of life in the South Bronx and what we as religious people might do about them. Groups were divided into English speaking and Spanish speaking. Each group focused on a particular project in the community: drugs, environment, health care, safety. We probed what light our religious faith shone on these issues. Each group chose a particular social problem to become informed on and to address in a concrete manner. Groups reported weekly on the 
progress they made in dealing with the problem. At the end of the course we had a powerful ceremony in which participants were commissioned as advocates for social improvement.

A few years ago I was interviewed by a graduate student in psychology who was conducting research on the scholarly habits on senior professors. Reflecting on the interview I realized that in answering questions I most often came back to describing the work I do in terms of mentoring masters and doctoral students. Mentoring Catherine in her ground breaking thesis changed my focus on what was now really important. It is less my own work that is important and more the work that students do both in their writing and in their careers. What keeps me deeply involved in religious educator these days is interest in the research projects and career aspirations of doctoral students. Perhaps this is what Erik Erikson described as fulfilling the need in older adults for a sense of generativity in order to avoid stagnation in one's life. The significance of mentoring in religious education, fruitfully explored by Leona English in her Mentoring and Religious Education, has deepened my appreciation for both the academic and nurturing potential of the religious education.

At its deepest level my vocation as religious educator is a vocation of love and friendship. Every teacher student relationship is one of potential friendship. The call to teach is a call to love and friendship. There is love between teacher and disciple. Some of my deepest loves and friendships are with former students. Many teachers have married a student of theirs, as I did. Sharing ideas, interests, and attitudes often begets a deep passion and a love. Unfortunately, it is a love that at times crosses boundaries. There are many cases of Abelard and Heloise. Exploitation, manipulation, and seduction are possible. But so is the nobility and beauty of genuine love and friendship.

Socrates and Plato discoursed on love between teachers and learners. Plato's Symposium eloquently describes this love. Jesus had disciples whom he loved and who loved him. One was even called the beloved disciple. The monastic tradition speaks of love between abbas and ammas and their disciples. Johann Pestalozzi and Maria Montessori have made love between teachers and students a primary principle of their pedagogy

These reflections on my vocation as a religious educator are from my perspective. Perhaps a more valid description my come from David, a student with whom I am joined with a bond of love and friendship. This may be too laudatory of me; but it does capture what I have attempted to do in my vocation as a religious educator.

For John

Plato,

Is that really you?

Aristotle, Augustine, Thomas

Is it true?

I heard you were gone

But you're here, singing in the pub 
With Sigmund who goes on and on

A baritone out of key

His pipe smelling of possibility.

John,

Is that you?

To laugh and sing, drink and talk

To joke and pry

The womb of "why".

Never too loud, too rough, too much

Always enough rational romance

Reaching the heart of a chance grace.

God,

Is that you?

\section{REFERENCES}

Chidester, David, 2000. Christianity: A Global History. San Francisco: HarperCollins, pp. 393-4)

Collins, Michael, 1991. Adult Education as Vocation, New York: Routledge.

Dewey, John. Dewey on education, Martin Dworkin, ed. New York: Teachers College Press, 1959.

Hadot, Pierre, 2002, What is Ancient Philosophy? Cambridge, MA, 56-7

Hellwig, Monika. Theological education in the undergraduate core curriculum. In Patrick Carey \& Earl Muller, eds., 1997. Theological Education in the Catholic Tradition: Contemporary Challenges. New York: Crossroads, 1997, 71-81.

Rahner, Karl, \& Vorgrimler, Herbert, 1995, Theological dictionary. New York: Herder and Herder, 483-4.

VanOosting, James, July 1-8, 2002,. America, 11-15. 